\title{
TRYPANOSOMA CRUZI: EXPERIMENTAL CHAGAS' DISEASE IN RHESUS MONKEYS. II. ULTRASTRUCTURAL AND CYTOCHEMICAL STUDIES OF PEROXIDASE AND ACID PHOSPHATASE ACTIVITIES
}

\author{
MARIA DE NAZARETH LEALDE MEIRELLES $/^{+}$; MARIA DA GLÓRIA BONECINI-ALMEIDA*; \\ MARIA HELEOSINA RIBEIRO PESSOA ${ }^{* *}$ \& BERNARDO GALVÃO-CASTRO*
}

\begin{abstract}
Instituto Oswaldo Cruz, Departamen to de Ultraestrutura e Biologia Celular *Departamento de Imunologia (WHO Colaborating Center for Research and Training in Parasitic Disease) Caixa Postal 926, 20001 Rio de Janeiro, RJ, Brasil **Universidade do Estado do Rio de Janeiro, Serviço de Microbiologia e Imunologia, Rio de Janeiro, RJ, Brasil
\end{abstract}

Ultrastructural and cytochemical studies of peroxidase and acid phosphatase were performed in skin, lymph node and heart muscle tissue of rhesus monkeys with experimental Chagas' disease. At the site of inoculation there was a proliferative reaction with the presence of immature macrophages revealed by peroxidase technique. At the lymph node a difuse inflammatory exudate with mononuclear cells, fibroblasts and immature activated macrophages reproduces the human pattern of acute Chagas' disease inflammatory lesions. The heart muscle cells present different degrees of degenerative alterations and a striking increase in the number of lysosomal profiles that exhibit acid hydrolase reaction product. A strong inflammatory reaction was present due to lymphocytic infiltrate or due to eosinophil granulocytes associated to ruptured cells. The present study provides some experimental evidences that the monkey model could be used as a reliable model to characterize histopathological alterations of the human disease.

Key words: ultrastructural cy tochemistry - peroxidase activity - acid phosphatase - Chagas' disease ... rhesus monkeys

Several experimental models have been tested with the purpose to obtain a reliable reproduction of human Chagas' disease. The majority of these models only reproduces one of the described stages of the disease (WHO, 1984; Andrade \& Grimaud, 1986; Brener \& Ramirez, 1985).

Many lines of evidence indicate that nonhuman primates are suitable model for Chagas' disease. Studies with these animals were performed using a species of the genus Cebus as well as squirrel monkeys (Magarino Torres \& Tavares, 1958; Bolomo et al., 1980; Rosner et al., 1988; Pung et al., 1988). Recently it was possible to confirm that rhesus monkeys reproduce at least the acute and indeterminate phase of the disease (Guimarães \& Miranda, 1961; Marsden et al., 1976; Seah et al., 1974; Bonecini-Almeida et al., 1990).

This work received support from FINEP (PINF 1) and CNPq.

+ Corresponding author.

Received September 13,1989.

Accepted January 4, 1990.
In this paper we analyse the ultrastructural cytochemistry alterations by observing mainly peroxidase and acid phosphatase activities of the lesions in the skin at the site of inoculation, the drainage lymph node and heart muscle tissue.

\section{MATERIALS AND METHODS}

Animals and experimental infection - Five rhesus monkeys experimentally infected with Trypanosoma cruzi (Colombiana strain) were sacrified at five, ten and eleven weeks after infection. Heart tissues were taken for ultrastructural studies. Biopsies of the site of inocu. lation in skin (Chagoma) and lymph node both taken on the 13th day after infection were also analysed. Details of the experimental infection are to be found in the previous paper (BoneciniAlmeida et al., 1990).

Transmission electron microscopy - Small pieces $(1 \mathrm{~mm})$ of skin, lymph node and heart muscle (atria and ventricles) were fixed either in $2,5 \% \mathrm{GA}$ or $1 \% \mathrm{PFA}$ plus $1 \% \mathrm{GA}$ in $0,1 \mathrm{M} \mathrm{Na}$ cacodylate buffer, $\mathrm{pH} 7.2$ for 1 hour or $30 \mathrm{~min}$, 


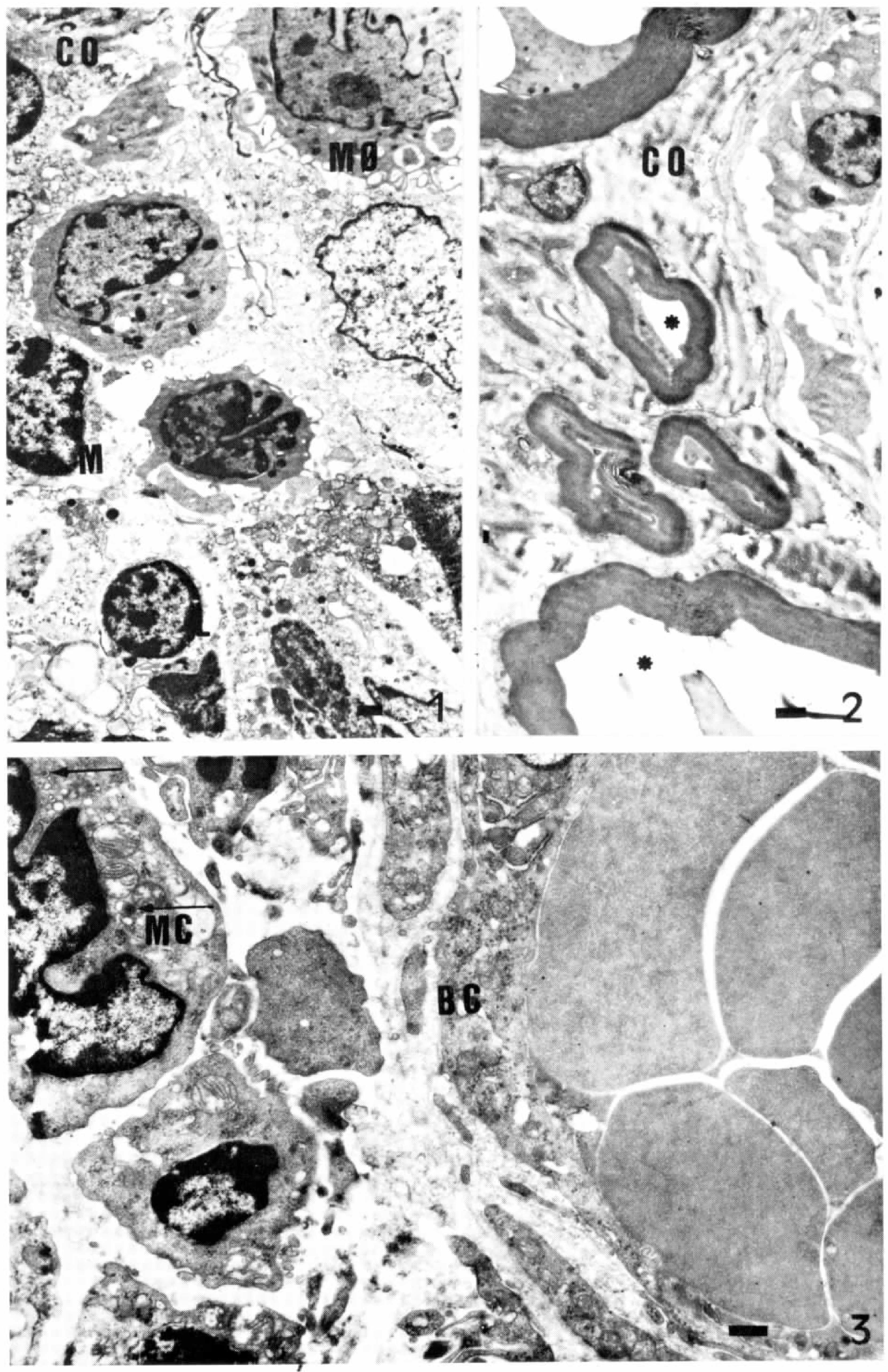

Fig. 1: general view of skin lesion 3 days old showing an inflammatory infiltrate of mononuclear cells with predominance of lymphocytes (L), monocytes (M) and macrophages (MO). Fig. 2: nerve sections show a pattern of disorganization in the mielinized fibers and a pronounced retraction in the axone $(*)$ Collagen deposits are seen in close proximity (CD). Fig. 3: congested blood capilary (BC) cells present the luminal space filled with erytrocytes (E) and monocytes. Monocuclear cells show peroxidase positive granules in the cytoplasm (MC). All bars are $0.5 \mu \mathrm{m}$. 

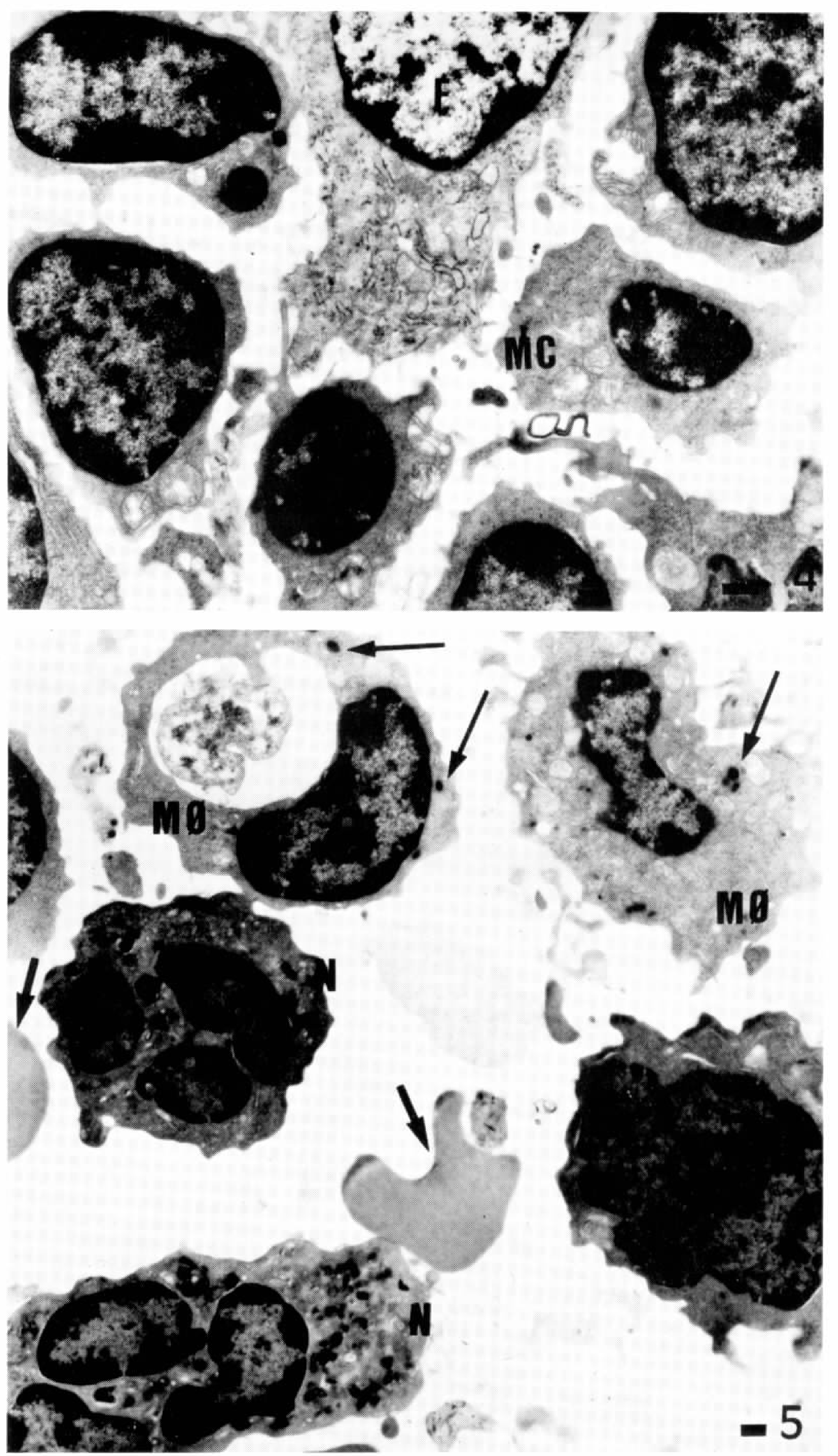

Fig. 4: lymphonode with mononuclear cells (MC); fibroblasts with enlarged endoplasmatic reticulum (F). Fig. 5: lymphonode showing the presence of large number of neutrophils $(\mathrm{N})$ with their characteristics granules, activated macrophages (MO) and a pronounced extravasation of red cells (arrow).

respectively, and rinsed in the same buffer. Then they were post-fixed with $1 \%$ OsO4. dehydrated in acetone and embedded in Epon.
Section were observed either unstained or stained with uranyl acetate and lead nitrate, in a EM 10B Zeiss Microscope. 
Ultrastructural cytochemistry - Horseradish peroxidase (E. C. 1.11.1.7.) - For ultrastructural studies, the small pieces of tissue were incubated in the presence of $2 \mathrm{mg} / \mathrm{ml}$ HRP (Sigma, type II) for $2 \mathrm{~h}$ at $37^{\circ} \mathrm{C}$, followed by a rinsage with PBS, and fixation in $2,5 \% \mathrm{GA}$ on

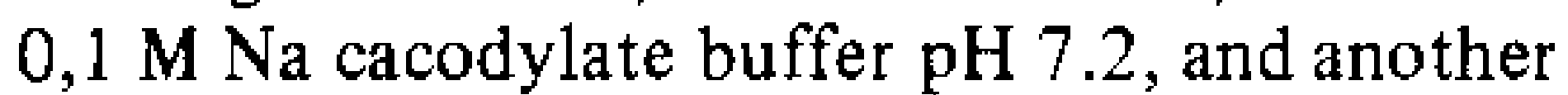
rinsage and then left overnight at $4^{\circ} \mathrm{C}$. The material was incubated for $30 \mathrm{~min}$ at room temperature in a medium containing 3,3'-diaminobenzidine $(0,5 \mathrm{mg} / \mathrm{ml})$ in $0,05 \mathrm{M}$ Tris hidroxymethyl aminomethane-HCl buffer $\mathrm{pH} 7.6$ and $0,01 \% \mathrm{H} 2 \mathrm{O} 2$, for detection of peroxidase activity (Graham \& Karnovsky, 1966) and processed for routine electron microscopy.

Acid Phosphatase (E. C. 3.1.3.2.) - For localization of the lysosomal enzyme acid phosphatase, small pieces of heart (atria and ventricles) were fixed with $1 \%$ PFA plus $1 \%$ GA for $30 \mathrm{~min}$ at $4^{\circ} \mathrm{C}$, washed with $\mathrm{Na}$ cacodylate buffer $\mathrm{pH} 7.2$ and incubated in the medium described by Ryters \& Bowers (1976) as follows: $0,05 \mathrm{M}$ calcium chloride, $11,5 \mathrm{mM} \mathrm{Na}$ B-glycerophosphate, $1 \mathrm{mM}$ cerium chloride in Tris-Maleate buffer $\mathrm{pH} 5.0$ and also processed for routine EM. The controls, were performed incubating the material in a medium:(a) without the substrate or (b) containing $10 \mathrm{mM} \mathrm{NaF}$.

\section{RESULTS}

Skin biopsies - The examination of skin lesions biopsies 13 days old, showed a considerable oedema and a proliferative reaction with the presence of an inflammatory infiltrate of mononuclear cells, mostly lymphocytes, monocytes and macrophages (Fig. 1). Nerve sections exhibited alterations with a pattern of disorganization of the myelinized fibers and axon retraction. Collagen deposits were present (Fig. 2). Endothelial cells were enlarged, blood capillaries were congested and filled with red blood cells. Monocytes present at the skin lesions showed positive peroxidase reaction (Fig. 3).

Lymphonode - The fragments of lymph node examined with 13 days of infection showed an inflammatory infiltration with predominance of lymphocytes, monocytes, macrophages, fibroblasts and collagen deposits. Macrophages with signs of activation and peroxidase positive granules were seen. Neutrophis were abundant and a pronounced extravasation of red blood cells was seen (Figs 4,5).
No parasites were detected in the lymph node examined.

Heart muscle tissue - Heart tissue from four monkeys at different times of infection was examined. They were sacrificed with five, ten and eleven weeks of infection. In all of them a common inflammatory response due to an infiltrate of mononuclear cells specially lymphocytes and macrophages was seen. Dissociation of the basal membrane and abundant collagen deposits were also observed (Fig. 6). Different grades of dissociation of fibers were noted and an increase in the lyososomal granules with a positive reaction for acid phosphatase was observed both in preserved and in well damaged cells (Figs 7,8). In one of the monkeys examined, with ten weeks of infection, a pronounced bulgy sarcolema both in the left atria and ventricle was noticed (Fig. 7). Sometimes two well preserved and very closely located cells, one with parasites and the other full with acid phosphatase reactive lysosomes could be seen (data nor shown). A lymphocyte infiltration was seen in the heart muscle cells in the majority of the monkeys studied showing different grades of damage as swelling of mitochondria, dilated $T$ tubules, acid phosphatase reactive lysosomes, bulgy sarcolemma (Figs 8,9 ). In a sample from a monkey examined with five weeks of infection an aggressive reaction to heart muscle fibers was seen due to a pronouced association of eosino. phils with the heart muscle fibers (Fig. 10). Well preserved $T$. cruzi infected fibers were seen at the left atria. Many sealed vesicles were observed around the parasite (Fig. 11). A common pattern was the looseness of the junctions at the intercalated disk seen in non parasitized but well damaged cells (Fig. 12). No reaction product was observed in a medium without substrate or containing $10 \mathrm{mM} \mathrm{NaF}$ (data not shown).

\section{DISCUSSION}

The difficulties of finding a reliable animal model that allows to follow the time course of the human Chagas' disease represent a great problem in the knowledge of the immuno. pathological evolution of this disease. Controlled conditions and systematic studies in such a model would clarify some questions related with the immunological early events that may be responsible for initiating the lesions in man or the mechanism of heart damage in chronic human disease. 

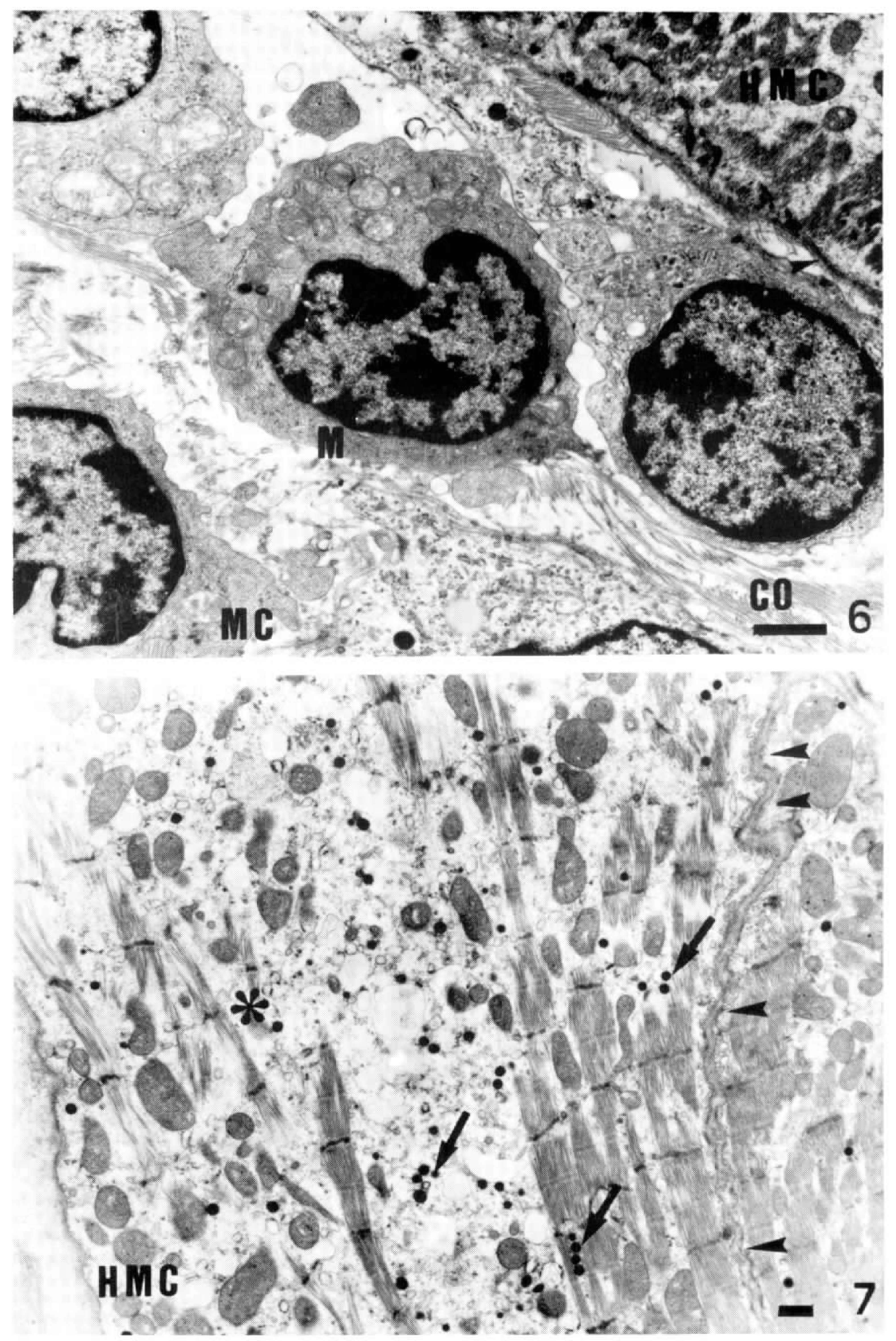

Fig. 6: damaged heart muscle cells (HMC) show an infiltrate of mononuclear cells (MC) with predominance of lymphocytes and monocytes. Dissociation of basal membrane (BM) and abundant collagen (CO) are a common feature. Fig. 7: localization of acid phosphatase in lysosomal profiles (arrows) in well damaged cells with an extensive oedeme, bulgy sarcolemme (arrow head) and dissociated myofibers (*).

The study of experimental Chagas' disease in different animals models has pointed to the difficulty in following the evolution of the intermediate and chronic phases in regard to their parasitological and immunological charac- terists. This is due to the insufficient data available or to experimental conditions that allow the survival of the innoculated animals (Brener \& Ramirez, 1985). 

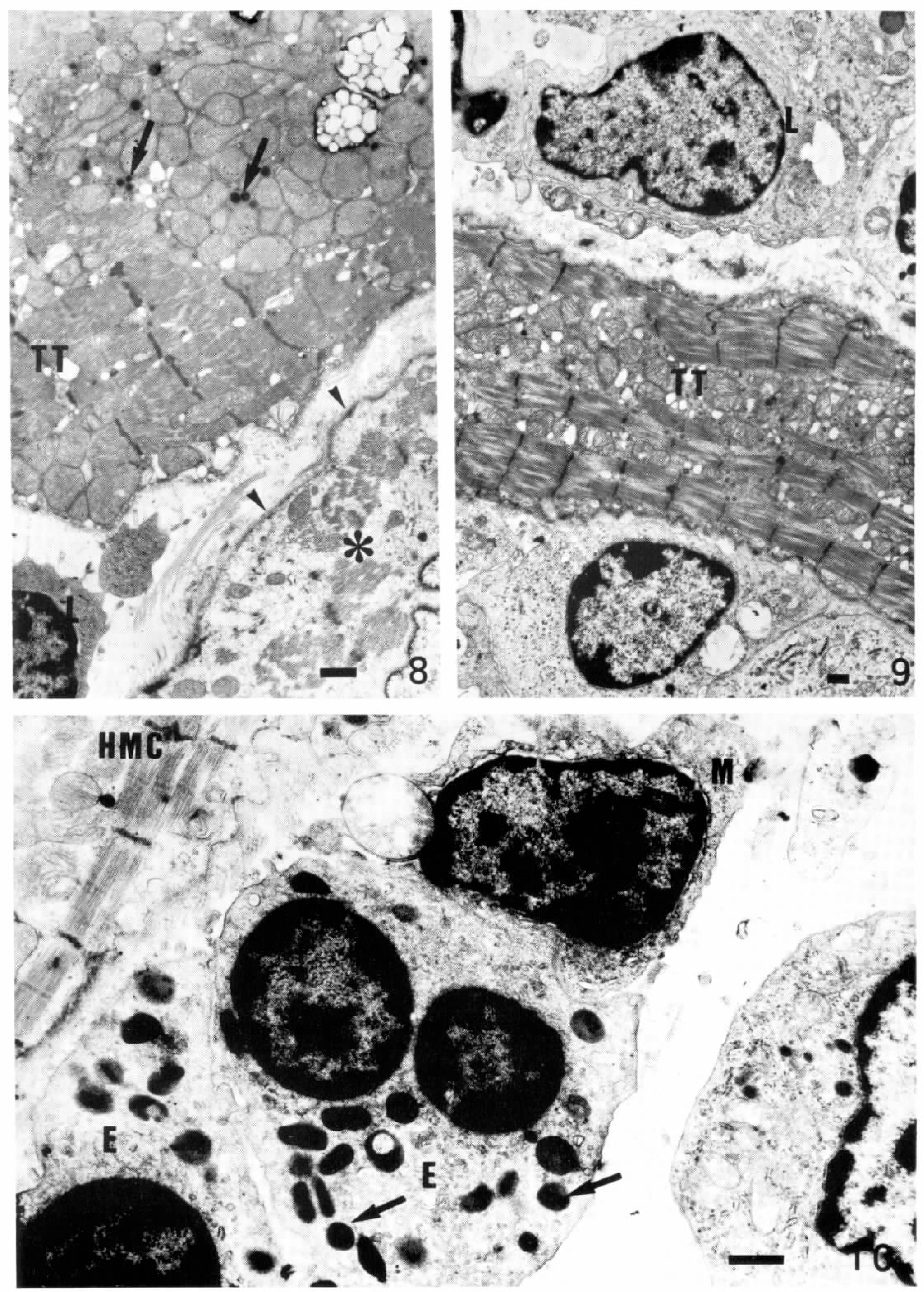

Figs 8-9: severe agressive reaction is seen in the monkey heart muscle cells: a lymphocyte infiltration in the proximity of cells that display great dissociation of the myofibers $\left({ }^{*}\right)$, swollen T- Tubules (TT), bulgy sarcolem $(\rightarrow)$ Reactive acid phosphatase lysosomal profiles (arrow). Fig. 10: eosinophils (E) with characteristic granules (arrow) are seen associated with heart muscle fibers and with monocytes (M). 

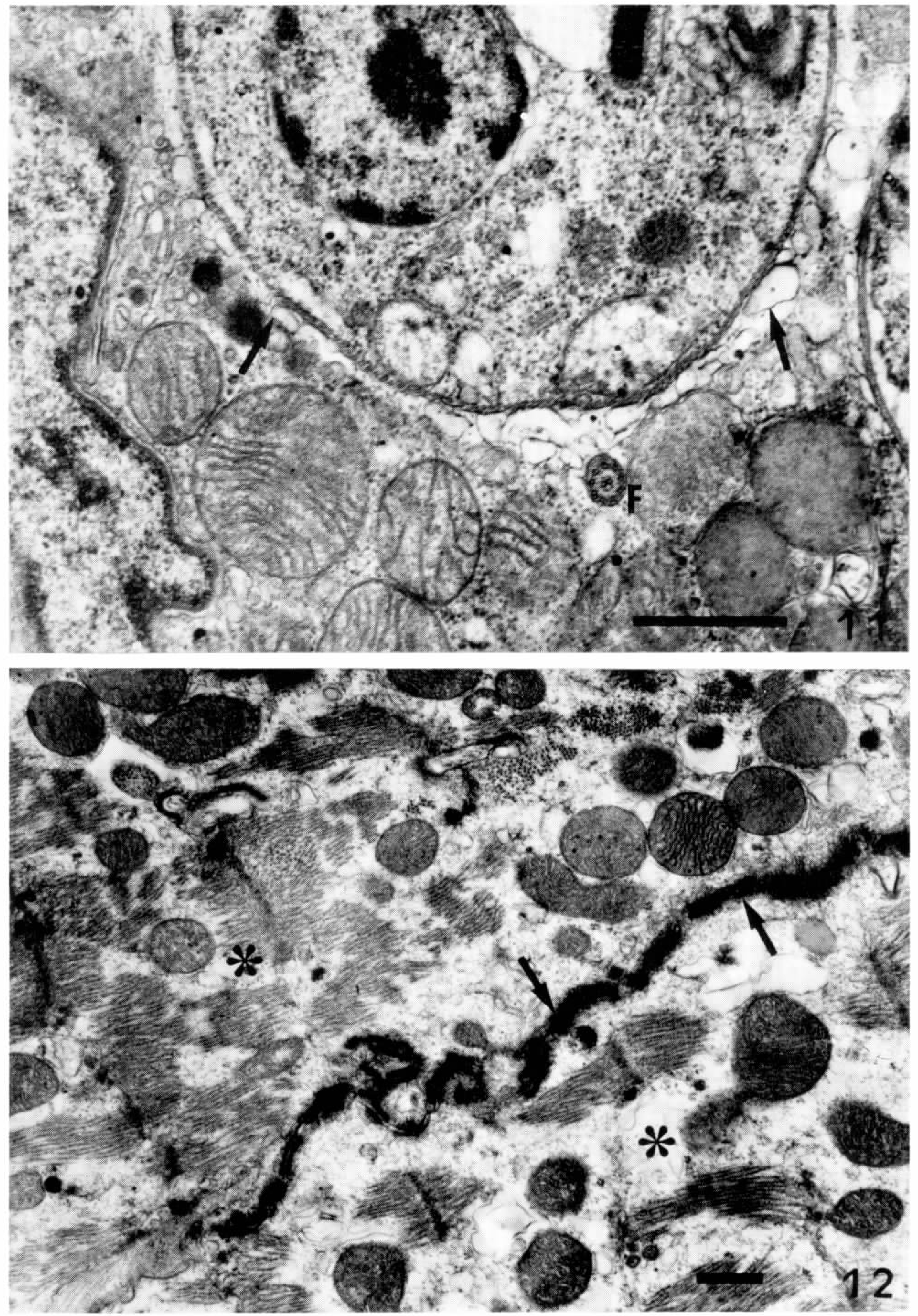

Fig. 11: left atria of heart muscle cell infected with Trypanosoma cruzi. Small vesicles are seen around the parasite (arrow), flagella of the parasite (F). Fig. 12: damaged cells without the presence of parasites show signs of looseness of the junctions (arrows), dilated mitochondria, oedema and great disorganization of myofibrils $(*)$ ).

Our previous report, (Bonecini-Almeida et al., 1990) points clearly that the rhesus monkey experimentally infected with $T$. cruzi reproduces the acute and intermediate stages of the human
Chagas' disease. As now stated many similarities were found at the site of inoculation, patent parasitaemia, pronounced lymphocytosis, electrocardiographical and histopathological alter- 
ations, hematological parameters, as well as the detection of $T$. cruzi antibodies, that resemble the human pattern.

An intense parasitism was observed in human heart muscle cells followed by focal inflammation after the rupture of the fibers (Vianna, 1911). The inflammatory exudate is constituted mainly by mononuclear cells, specially macrophages, lymphocytes and few plasma cells. This response causes dissociation of the muscle cells, pushing apart the myofibrils and other organelles leading to many degenerative changes (Tafuri, 1985; Andrade, 1983). In systems in vitro factors as the one related with the parasite or related with the host may influence the acute myocarditis pattern.

There are few reports concerning the early events of the interaction and local changes that follow the infection of $T$. cruzi in mammalian hosts. A recent report (Bijovsky \& Milder, 1988 ) about the inoculation of the parasites in a peculiar region devoid of lymphatic vessels the cheekpouch of hamsters - showed the persistance of parasites until 15-20 days after inoculation followed by their disappearance of this local around 28 days with the presence of an infiltrate of mononuclear cells, plasmocytes and macrophages.

In the present paper, examination at the site of inoculation showed a proliferative reaction with the presence of lymphocytes, activated fibroblasts, eosinophil granulocytes and immature macrophages revealed by peroxidase technique. In addition, oedema alterations in the myelinized axones and congested blood vessels were observed. The finding of a positive reaction in the granules of some mononuclear cells at the skin of the rhesus monkeys correlates with the pattern of cell-mediated immune response in this local.

At the lymph node a diffuse inflammatory exudate of monocytes and lymphocytes, as well as fibroblast with dilatated endoplasmic reticulum, neutrophil granulocytes, rare mastocytes were seen. Oedema and immature activated macrophages with peroxidase positive granules were present, data that reproduce the human pattern of acute Chagas' disease inflammatory lesions.

The present study demonstrates that heart muscle cells could be seen with different degrees of degenerative signs showing electron microscopic alterations that resemble the signs of damage of a severe myocarditis pattern. A strong inflammatory reaction was present due to lymphocytic infiltrate that was seen at very close proximity of the fibers, in most of cases, or due to eosinophil granulocytes associated to the ruptured cells suggesting a role of the immune response in the reaction. Both aspects are already described in the literature for the human disease (Tafuri, 1985). In some cases, in left atria, we observed parasites free in the cytoplasm of well preserved cells, surrounded by abundant sealed vesicles. These signs could be an end product of the lysis of the endocytic vacuole where the parasite could be initially found, as previously demonstrated in in vitro muscle culture systems (Meirelles et al., 1986). In vitro systems of both macrophages and heart muscle cells showed clearly the initial events of the interiorization of $T$. cruzi revealing the presence of the parasite within the phagosome immediately after its interiorization (Meirelles et al., 1986; Nogueira \& Cohn, 1976). Sometimes normal fibers with an increase of lysosomal profiles were seen near infected cells with no signs of damage. We noticed a striking increase in the number of lysosomal profiles that exhibit acid hydrolase reaction products in heart tissue. It is interesting that the increase in the lysosomal granules were seen in cells without parasites, both with normal aspect and with graded signs of disturbance. There are some experimental evidences (Decker \& Wildenthal, 1978; Decker et al., 1980) supporting the hypothesis that lysosomal changes may somehow be linked to the damage sustained by the cells during certain disease. An important field of research in the monkey model will be the search of the role of lysosomal hydrolases in producing tissue damage and contributing to the cellular alterations that accompanies cell death.

The present study provides some experimental evidences that the monkey model, like the human being, develops, a serie of sequential alterations that resemble the morphological signs of the Chagas' disease and could be used within well controlled conditions as a reliable model to characterize the human disease.

\section{ACKNOWLEDGEMEINTS}

To Mr Levi Marques da Silva, Mr Generval Luciano Baptista, the Setor of Multi-Meios 
(FIOCRUZ) for the technical assistance and to the secretarial assistance of Mrs Maria José Couto.

\section{REFERENCES}

ANDRADE, S. G. \& GRIMAUD, J. A., 1986. Chronic murine myocarditis due to Trypanosoma cruzi. An ultrastructural study and immunochemical characterization of cardiac intersticial matrix. Mem. Inst. Oswaldo Cruz, 81:29.41.

ANDRADE, Z. A., 1983. Mechanisms of myocardial damage in Trypanosoma cruzi infection. In Cyto. phatology of parasitic diseases. Ciba Found. Symp., 99: 214-233.

BIJOVSKY, A. T. \& MLLDER, R., 1988. Ultrastructural analysis of the interaction between host cells and Trypanosoma cruzi in experimental chagomas. Trans. R. Soc. Trop. Med. Hyg., 82: 704-708.

BOLOMO, N.; MILEl, J.; COSSIO, P. M.; SEGURA, E. L.; LAGUENS, R. P.; I'ERNANDEZ, L. M. \& ARAN̄A, R. M., 1980. Experimental Chagas' disease in a South America primate (Cebus sp). Medicina (Buenos Aires), 40:667-672.

BONECINI-ALMEIDA, M. G.; PESSOA, M. H. R.; PIRMEZ, C. ; LARANJA, $\mathrm{F}$. \& GALVÃO-CASTRO, B., 1990. Trypanosoma cruzi. experimental Chagas' disease in rhesus monkeys. 1. Clinical, parasitolo. gical, haematological and anatomopathological studies in the acute and indeterminate phases. $\mathrm{Mem}$. Inst. Oswaldo Cruz, 85:

BRENER, Z. \& RAMIREZ, L. E., 1985. Modelo Cronico da Doença de Chagas Experimental. In R. Cançado \& M. Chuster, Cardiopatia Chagásica (Cap. III) Fundação Carlos Chagas, Belo Horizonte, MG, Brasil.

DECKER, R. S.; CRIE, J. S.; POOLE, A. R.; DINGLE, J. T. \& WILDENTHAL, K., 1980. Resistance to ischemic damage in hearts of starved rabbits. Correlation with ly sosomal alterations and delayed release of cathepsin. D. Lab. Invest., 43:197-207.

DECKER, R. S. \& WILDENTHAL, K., 1978. Sequential lysosomal alterations during cardiac ischemia. II. Ultrastructural and Cytochemical changes. Lab. Invest, , 38: 662-673.

GRAHAM, R. C. \& KARNOVSKY, M. J., 1966. The early stages of absortion of injected horseradish peroxidase in the proximal tubules of mouse kidney: ultrastructural cytochemistry by a new technique. J. Histochem. Cytochem., 14:291 -302.

GUIMARÄES, J. P. \& MIRANDA, A., 1961 . Megaesôfago em macaco Rhesus com 10 anos de infecçāo chagásica. Anais do Congresso Internacional sobre
Doença de Chagas, Rio de Janeiro, 2: 562-571.

MAGARINO TORRES, C. \& TAVARES, B. M., 1958. Miocardite no macaco Cebus após inoculaçōes repetidas com Schizotrypanum cruzi. Mem. Inst. Oswaldo Cruz, 56:85-152.

MARSDEN, P. D.; SEAH, S. K. K.; DRAPPER, C. C.; PETTIT, L. E.; MILES, M. A. \& VOLLER, A., 1976. Experimental Trypanosoma cruzi infection in Rhesus monkey. II. The early chronic phase. Trans. R. Soc. Trop. Med. Hug., 70: 247.251.

MEIRELLES, M. N. M., ARAUJO JORGE, T. C., MIRANDA, C. F.; DE SOUZA, W. \& BARBOSA, H. S., 1986. On the interaction of Trypanosoma cruzi with heart muscle cell: Ultrastructural and cytochemical analysis of endocytic vacuole formation and effect upon myogeneis in vitro. Eur. J. Cell. Biol., $41: 198-205$.

NOGUEIRA, N. \& COHN, Z., 1976. Trypanosoma cruzi: mechanisms of entry and intracellular fate in mammalian cells. J. Exp. Med., 143: 14021420 .

PUNG, O. J.; HULSEBOS, L. H. \& KUHN, R. E., 1988. Experimental Chagas' disease (Trypanosoma cruzi) in the Brazilian squirrel (Saimiri sciurrus): Hematology, Cardiology, Cellular and Humoral immune Response. Int. J. Parasitol., 18: 115-120.

ROSNER, J. M.; SCHININI, A.; ROVIRA, T.; VELASQUES, G.; MONZON, M. I.; MALDONADO, M.; FLRRO, E. A. \& GALEANO, R., 1988. Acute Chagas' Disease in non-human primates. 1. Chronology of clinical events, clinical chemistry, ECG, radiology, parasitemia and immunological parameters in the Cebus apella monkey. Trop. Med. Parasitol., 39:51-55.

RYTERS, A. \& BOWERS, B., 1976. Localization of acid phosphatase in Acanthamoeba castellani with light and electron microscopy during growth and after phagocytosis, $J$. Ultrastruct. Res., 57: 309. 321.

SEAH, S. K. K.; MARSDEN, P. D.; VOLlER, A. \& PETTIT, L. E., 1974. Experimental Trypanosoma cruzi infection in Rhesus monkeys. The acute phasc. Trans. R. Soc. Trop. Med. Hug., 68:63-69.

TAl.URI, W. L., 1985. Patogênese. In R. Cançado \& M. Chuster, Cardiopatia Chagdsica (cap 1). Fundação Carlos Chagas, Belo Horizonte, MG, Brasil.

VIANNA, G., 1911. Contribuição para o estudo da anatomia patológica da moléstia de Carlos Chagas. Mem. Inst. Oswaldo Cruz, 3: 272-294.

WORLD HEALTH ORGANIZATION, 1984. Report of the Scientific Working Group on the development and evaluation of animal models for Chagas' Disease. Genève, July, p. 23-24. TDR/ IMMCHA-AMDD/84.3. 